\title{
ANTAGONISTIC PROPERTIES OF SOME MICROORGANISMS ISOLATED FROM BRAZILIAN TROPICAL SAVANNAH PLANTS AGAINST Staphylococcus COAGULASE-POSITIVE STRAIN
}

\author{
RATTI R. P. (1), SERRANO N. F. G. (1), HOKKA C. O. (1, 2), SOUSA C. P. (1, 3)
}

(1) Graduation Program in Biotechnology (PPG-Biotec), Federal University of São Carlos, UFSCar, São Carlos, São Paulo State, Brazil; (2) Department of Chemical Engineering, UFSCar, São Carlos, São Paulo State, Brazil; (3) Department of Morphology and Pathology, UFSCar, São Carlos, São Paulo State, Brazil.

\begin{abstract}
Endophytic microorganisms are relatively unstudied as potential sources of novel natural products for medical and commercial exploitation. The aim of this work was to investigate some Brazilian tropical savannah trees Cassia leptophylla and Prunus spp. in order to isolate the endophytic microorganisms associated with these plants. The samples were disinfected to eliminate the epiphytic population. Colonies were diluted and displayed as drops in media and growing colonies were inactivated. Staphylococcus coagulase-positive strain was used as indicator microorganism and subjected to the antibioses test. Data showed that the microorganisms isolated from Cassia leptophylla had no inhibition against Staphylococcus. On the other hand, microorganisms isolated from Prunus spp. leaves showed antibacterial activity and inhibited Staphylococcus when cultivated in peptone agar as well as in yeast extract agar. Investigation proceeds in order to classify the isolated microorganisms presenting bioactive substance and exploit the potential of the compounds produced to inhibit the indicator bacteria. Other bioactive properties will be investigated.
\end{abstract}

KEY WORDS: endophytic microorganisms, plants, antibacterial activity, bioactive compounds.

CONFLICTS OF INTEREST: There is no conflict.

\section{CORRESPONDENCE TO:}

CRISTINA PAIVA DE SOUSA, Departamento de Morfologia e Patologia, Rodovia Washington Luis (SP-310), Km 235, 13565-905, São Carlos, SP, Brasil. Phone: 55 163351 8760. Fax: 55163351 8326. Email: prokarya@.ufscar.br. 
R. P. Ratti et al. ANTAGONISTIC PROPERTIES OF SOME MICROORGANISMS ISOLATED FROM BRAZILIAN TROPICAL SAVANNAH PLANTS AGAINST Staphylococcus COAGULASE-POSITIVE STRAIN.J. Venom. Anim. Toxins incl. Trop. Dis., 2008, 14, 2, p. 295

\section{INTRODUCTION}

The need for new and useful compounds to provide assistance and relief in all aspects of human condition is ever-growing. Drug resistance in bacteria, the appearance of life-threatening viruses, and the increase in the incidence of fungal infections in the world's population all underscore our inadequacy to cope with these medical problems. Endophytic microorganisms that colonize internal tissues of plants without causing any negative effects are relatively unstudied as potential sources of novel natural products for medical and commercial exploitation. Some endemic plants having an unusual longevity can generate bioactive natural products associated with endophytic microorganisms that produce the same natural products (1). Presumably, the simplest biological arrangement between these organisms is that the plant provides nutrition for the microbe and this one provides some form of protection for the plant. Endophytes promote plant growth and yield, suppress pathogens, may help to remove contaminants, solubilize phosphate, or contribute to assimilate nitrogen to plants (12). Brazilian tropical savannah plants are likely to be excellent specimens to begin a search for endophytic microorganisms $(11,15)$. In Brazilian tropical savannah soils with native plants, the natural populations of actinomycetes in the microbiota can be superior to $75 \%$, with predominance of the genera Streptomyces $(6,8,16)$. As a group, the Streptomycetes provide nearly $80 \%$ of all of the world's antibiotics produced $(3,4)$. A search reveals that most of these organisms have their origins in soil (10), and another biologically important niche that has been overlooked as a source of novel are the tissues of higher plants. This specialized and unique biological niche that supports the growth of microbes is the intracellular space between cells of higher plants. Novel endophytes usually have associated with them novel secondary natural products (17).

The aim of this work was to investigate the Brazilian tropical savannah trees Cassia leptophylla and Prunus spp. in order to isolate the associated endophytic microorganisms with potential for producing antibacterial substances.

\section{MATERIALS AND METHODS}

The Brazilian tropical savannah plants Cassia leptophylla and Prunus spp. were collected in an ecological reserve at São Carlos, São Paulo State, Brazil, and analyzed at the Microbiology Laboratory, at Federal University of São Carlos. 
R. P. Ratti et al. ANTAGONISTIC PROPERTIES OF SOME MICROORGANISMS ISOLATED FROM BRAZILIAN TROPICAL SAVANNAH PLANTS AGAINST Staphylococcus COAGULASE-POSITIVE STRAIN.J. Venom. Anim. Toxins incl. Trop. Dis., 2008, 14, 2, p. 296

To eliminate the epiphytic population, the plants (leaves and caulis) were washed with distilled sterile water and neutral detergent and its surface disinfected with ethanol (70\%/1min), sodium hypochlorite (2\%/6min) and ethanol (70\%/30s) and consecutively rinsed with distilled sterile water (10). The surface-disinfected plants were then aseptically sectioned into $0.5+/-0.7 \mathrm{~cm}$ fragments, distributed onto the isolation media, yeast extract agar (YE) and peptone agar (PA), and incubated at room temperature for 4 days. At the same time, the disinfected plants were homogenized with peptone water 0.1\% (1:9). Decimal dilutions were made and $100 \mu \mathrm{l}$ aliquots were displayed on the surface of agar medium and incubated (room temperature/4 days). From each of these plates, some colonies representing different morphologies were then picked. Preliminary microbial identification using Gram and Ziehl-Neelsen staining, melanin production and catalase activity were done. Selected colonies were diluted in peptone water $(0.1 \%)$ and displayed as drops (Pasteur pipette) in PA and YE as an additional part. Petri dishes were incubated (room temperature, and $37^{\circ} \mathrm{C} / 48 \mathrm{~h}$ ). The bioassays were conducted using growing colonies in PA and YE and inactivating them by chloroform (20min). Plates were opened (30min) to evaporate the substance. At the same time, the reactivation of Staphylococcus coagulase-positive strain ( $\mathrm{BHI}$ broth $24 \mathrm{~h} / 37^{\circ} \mathrm{C}$ ) was made and one aliquot was used as the indicator microorganism. $200 \mu$ of the culture properly reactivated was transferred to $10 \mathrm{ml}$ of semi solid $\mathrm{BHI}$ medium and shaken. This mixture was deposited onto the surface of plates containing the inactivated microorganisms and incubated $\left(37^{\circ} \mathrm{C} / 48 \mathrm{~h}\right)$ for the observation of inhibition halos.

\section{RESULTS}

Ten colonies, chosen among those isolated from Cassia leptophylla and Prunus spp., were selected. Data showed that the microorganisms isolated from Cassia leptophylla had no antibiosis against Staphylococcus coagulase-positive strain when cultivated in PA and YE (Figure 1).

The macroscopic evaluations of one isolate from Prunus spp. were made. The observation of growing colonies in PA and YE were made by visual inspection of the morphological characteristics. The isolated microorganism showed different growing aspects when cultivated in these media (room temperature/48h). In YE, the colonies were yellowish, big, glowing and mucous, and in PA, white, small and with irregular borders (Figure 2). 
R. P. Ratti et al. ANTAGONISTIC PROPERTIES OF SOME MICROORGANISMS ISOLATED FROM BRAZILIAN TROPICAL SAVANNAH PLANTS AGAINST Staphylococcus COAGULASE-POSITIVE STRAIN.J. Venom. Anim. Toxins incl. Trop. Dis., 2008, 14, 2, p. 297

Gram-positive bacilli and spores as well as bacilli with one or two apical spores in Gram staining were observed, suggesting that only one propagule was isolated. No alcohol-acid cells in Ziehl-Neelsen staining were observed. It was not observed the melanoid pigment production. The catalase activity was positive. The investigation continues in order to identify the isolated endophytic microorganism.

The microorganisms isolated from Prunus spp. leaves showed distinct inhibition zones against Staphylococcus coagulase-positive sirain. The white colony showed antibacterial activity against Staphylococcus, with inhibition zones of $1.6 \mathrm{~cm}$ and $2.1 \mathrm{~cm}$ diameter in media when cultivated in PA and YE, respectively (Figure 3). Similarly, the inhibition of Staphylococcus by the other isolated microorganism (yellowish colony) presented inhibition zone of $2.0 \mathrm{~cm}$ and $1.4 \mathrm{~cm}$ diameter in media when cultivated in YE and PA, respectively (Figure 4).

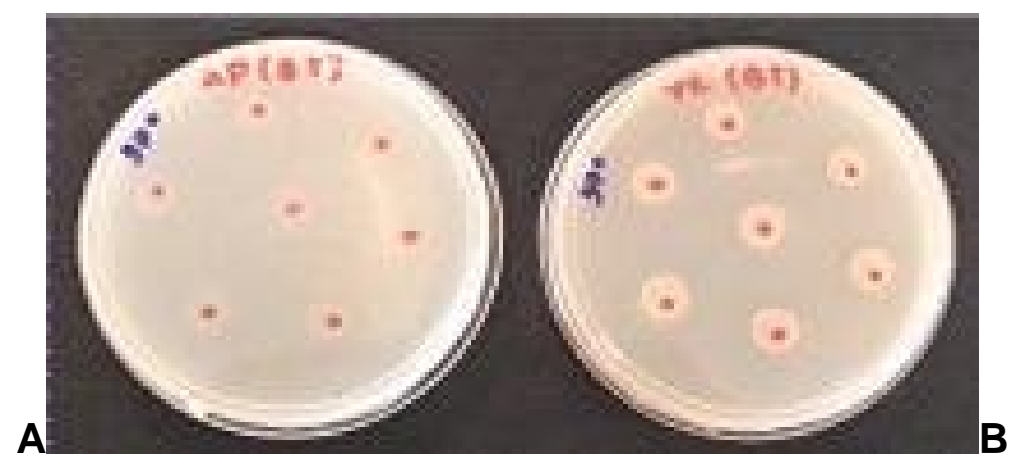

Figure 1. The isolated microorganism from Cassia leptophylla showed no inhibitory activity against Staphylococcus coagulase-positive strain in peptone agar (A) and yeast extract agar (B).

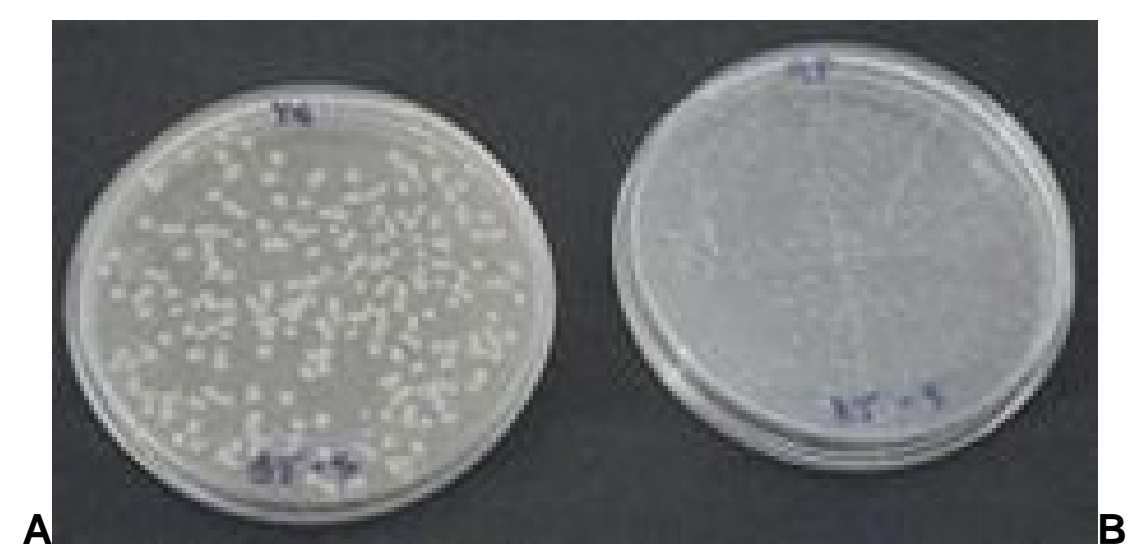


R. P. Ratti et al. ANTAGONISTIC PROPERTIES OF SOME MICROORGANISMS ISOLATED FROM BRAZILIAN TROPICAL SAVANNAH PLANTS AGAINST Staphylococcus COAGULASE-POSITIVE STRAIN.J. Venom. Anim. Toxins incl. Trop. Dis., 2008, 14, 2, p. 298

Figure 2. Macroscopic evaluations of the colonies growing in yeast extract agar (A) and peptone agar (B).

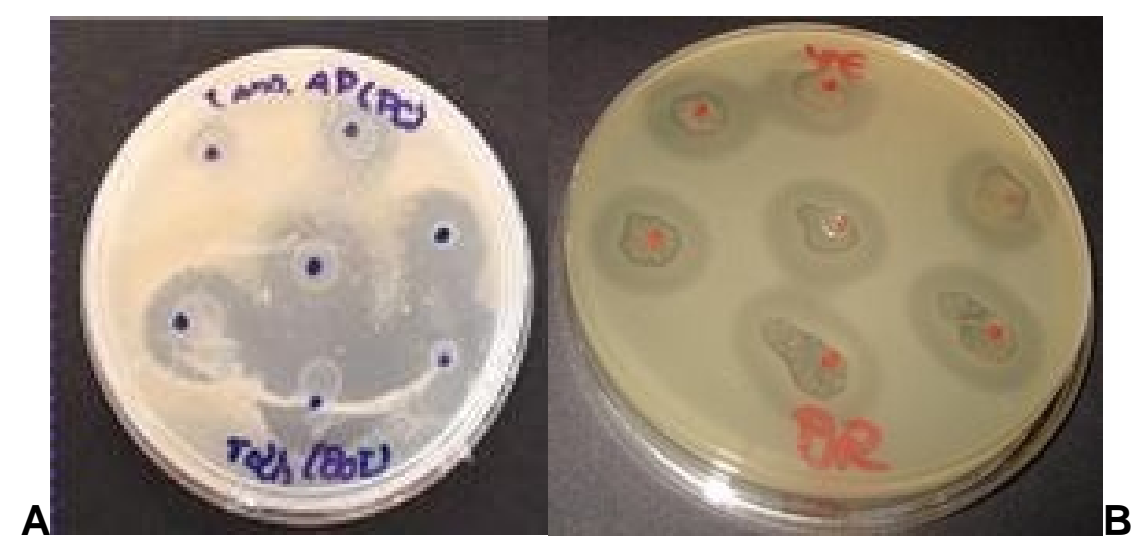

Figure 3. The isolated microorganism from Prunus spp. leaves (white colony) showed inhibition halos against Staphylococcus coagulase-positive strain in peptone agar (A) and yeast extract agar (B).

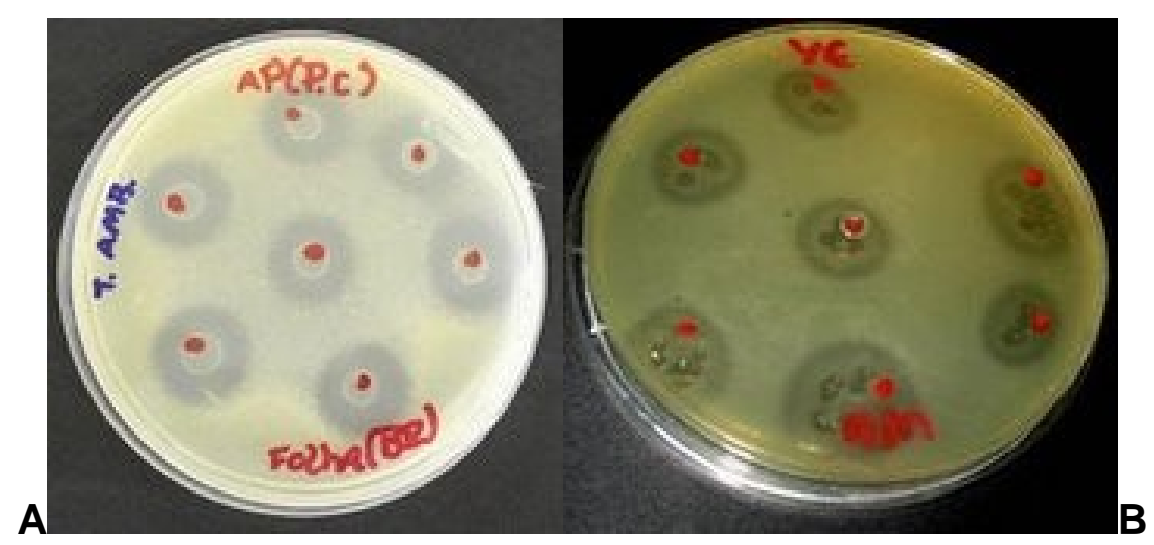

Figure 4. The isolated microorganism from Prunus spp. leaves (yellowish colony) showed inhibition halos against Staphylococcus coagulase-positive strain in peptone agar (A) and yeast extract agar (B).

\section{DISCUSSION}

In Pernambuco state, Brazil, Brito (2) isolated actinomycetes from beans (Phaseolus vulgaris). They showed that $6 \%$ of the isolated microorganisms had antibiotic activity against Staphylococcus aureus and Bacillus subtilis. In this present study, the isolated microorganisms from Prunus spp. showed activity against the tested Staphylococcus coagulase-positive strain. 
R. P. Ratti et al. ANTAGONISTIC PROPERTIES OF SOME MICROORGANISMS ISOLATED FROM BRAZILIAN TROPICAL SAVANNAH PLANTS AGAINST Staphylococcus COAGULASE-POSITIVE STRAIN.J. Venom. Anim. Toxins incl. Trop. Dis., 2008, 14, 2, p. 299

Sardi et al. (14), working in Italy with about 500 endophytic actinomycetes isolated from roots from 28 different plants, showed that the Streptomyces were the predominant isolated genera.

In Brazil, Matsuura (7) isolated 31 endophytic actinomycetes from roots and leaves from caupi beans (Vigna unguiculata), with special attention to Streptomyces followed by Streptosporangium and Nocardiopsis. According this author, 20\% of the isolated microorganisms presented antimicrobial activity against Gram-positive bacteria and Candida albicans.

Yoo et al. (18) analyzed the capability of the Streptomyces spp. CS684 in order to inactivate methicillin-resistant Staphylococcus aureus (MRSA) and vancomycinresistant enterococci (VRE). Data showed that the Streptomyces spp. CS684 presented antibacterial activity against MRSA and VRE.

Gu et al. (5) analyzed the capability of Streptomyces roseosporus strain in the inhibition of Staphylococcus aureus and showed that the S. roseosporus strain exhibited potent antibacterial activity against $S$. aureus.

Parvateesam and Bulchandani (9) showed that several strains of actinomycetes were isolated from soil samples collected from various localities of Ajmer District, India. These isolates were tested for their antagonistic properties against few test organisms like Bacillus subtilis, Escherichia coli, Pseudomonas aeruginosa, Staphylococcus spp., Saccharomyces cerevisiae and Aspergillus niger. Some of these actinomycetes strains exhibited antimicrobial activity against bacteria, but no antifungal activity was observed.

A total of 90 different Streptomyces isolates were recovered from 36 soil samples and assessed for their antibacterial activity (13). The antibiotic activity against a wide range of bacteria was exhibited by $54 \%$ of the isolates which were effective against B. subtilis (57\%), S. aureus (47\%), E. coli (24\%), Klebsiella spp. (16\%), and Shigella spp. (12\%). The lowest activity (8\%) was exhibited against Pseudomonas spp. and Salmonella spp. The antibacterial activity of the isolates was divided into four groups according to the diameter of the produced inhibition zone. Groups 3 and 4 with larger inhibition zones indicated their potential as a possible source of novel antibiotics. In this respect, our results $(2.14 \mathrm{~cm}$ diameter media) probably are pointing to the isolation of an antibacterial compound. 
R. P. Ratti et al. ANTAGONISTIC PROPERTIES OF SOME MICROORGANISMS ISOLATED FROM BRAZILIAN TROPICAL SAVANNAH PLANTS AGAINST Staphylococcus COAGULASE-POSITIVE STRAIN.J. Venom. Anim. Toxins incl. Trop. Dis., 2008, 14, 2, p. 300

Data exhibited here suggests that Brazilian tropical savannah plants are good source to search endophytic microorganisms, emphasizing the potential of natural compounds that can be used in agriculture, clinics and pharmaceutical industry.

The high commercial potential of natural substances and the upcoming threat of multidrug resistant pathogens have brought research on actinomycetes into focus again during the last years.

In conclusion, endophytic microorganisms are a very promising source for production of bioactive compounds. Investigation proceeds in order to classify the microorganisms and exploit the potential of the substance produced to inhibit pathogenic bacteria.

\section{ACKNOWLEDGEMENTS}

This work was supported by the São Paulo State Research Foundation [Fundação de Amparo à Pesquisa do Estado de São Paulo - FAPESP] (05/55079-4). 
R. P. Ratti et al. ANTAGONISTIC PROPERTIES OF SOME MICROORGANISMS ISOLATED FROM BRAZILIAN TROPICAL SAVANNAH PLANTS AGAINST Staphylococcus COAGULASE-POSITIVE STRAIN.J. Venom. Anim. Toxins incl. Trop. Dis., 2008, 14, 2, p. 301

\section{REFERENCES}

1 ADELEYE IA., ERUBA S., EZEANI CJ. Isolation and characterization of antibiotic producing microorganisms in composted Nigerian soil. J. Environ. Bio., 2004, 25, 313-6.

2 BRITO KC. Isolamento e atividade antimicrobiana de actinomicetos endofíticos do feijão (Phaseolus vulgairs). Recife: Universidade Federal de Pernambuco, 1998. 42p. [Monografia].

3 CHALLIS GL., HOPWOOD DA. Synergy and contingency as driving forces for the evolution of multiple secondary metabolite production by Streptomyces species. Proc. Nat. Acad. Sci., 2003, 100, 14555-61.

4 GOMES RC., SEMEDO LTAS., SOARES RMA., LINHARES LF., ULHOA CJ., ALVIANO CS. Purification of thermostable endochitinase from Streptomyces RC1071 isolated from a cerrado soil and its antagonism against phytopathogenic fungi. J. Appl. Microbiol., 2001, 90, 653-61.

5 GU J-Q., NGUYEN KT., GANDHI C., RAJGARHIA V., BALTZ RH., BRIAN P. Structural characterization of daptomycin analogues A21978C1-3(d-Asn11) produced by a recombinant Streptomyces roseosporus strain. J. Nat. Prod., 2007, 70, 233-40. 6 HASEGAWA T., TAKIZAWA M., TANIDA S. A rapid analysis for chemical grouping of aerobic actinomycetes. J. Gen. Appl. Microbiol., 1983, 29, 319-22.

7 MATSUURA T. Ocorrência de actinomicetos endofíticos produtores de antibióticos de folhas e raízes do feijão caupi (Vigna unguiculata). Recife: Universidade Federal de Pernambuco, 1998. 69p. [Master's Thesis].

8 MOURA AB., ROMEIRO RS. Avaliação in vitro de actinomicetos como antagonistas a Ralstonia solanacearum. Ci. Agrotec., 1999, 23, 281-8.

9 PARVATEESAM M., BULCHANDANI BD. Screening of actinomycetes isolated from soil samples of Ajmer, Rajasthan for antimicrobial activity. Hindustan Antibiot. Bull., 2004, 45, 22-8.

10 PEREIRA JC., NEVES MCP., DROZDOWICZ A. Quantificações das populações de bactérias em geral, de bactérias resistentes a antibióticos e de actinomicetos em solos. Seropédica: Embrapa-CNPAB, 1996. 20p. (Embrapa-CNPAB. Documentos, 26).

11 RATTI RP., SERRANO NFG., HOKKA CO., SOUSA CP. Caracterização e melhoramento genético de linhagens de Streptomyces isolados do cerrado da região 
R. P. Ratti et al. ANTAGONISTIC PROPERTIES OF SOME MICROORGANISMS ISOLATED FROM BRAZILIAN TROPICAL SAVANNAH PLANTS AGAINST Staphylococcus COAGULASE-POSITIVE STRAIN.J. Venom. Anim. Toxins incl. Trop. Dis., 2008, 14, 2, p. 302

de São Carlos (SP) e potencialmente produtoras de substâncias bioativas. In: SEMINÁRIO DO PROJETO TEMÁTICO FAPESP, 1, São Carlos, 2007. Anais... São Carlos: EDUFSCar, 2007, v.1, p.15-6.

12 ROSENBLUETH M., MARTINEZ-ROMERO E. Bacterial endophytes and their interactions with hosts. Mol. Plant. Microbe. Interact., 2006, 19, 827-37.

13 SAADOUN I., AL-MOMANI F., MALKAWI HI., MOHAMAD MJ. Isolation, identification and analysis of antibacterial activity of soil streptomycetes isolates from north Jordan. Microbios, 1999, 100, 41-6.

14 SARDI P., SARACCHI M., QUARONI S., PETROLINI B., BORGONOVI GE., MERLI S. Isolation of endophytic Streptomyces strains from surface-sterilized roots. Apll. Environ. Microbiol., 1992, 58, 2691-3.

15 SERRANO NFG., RATTI RP., HOKKA CO., SOUSA CP. Isolamento e identificação de Streptomyces endofíticos no cerrado da região de São Carlos (SP). In: SEMINÁRIO DO PROJETO TEMÁTICO FAPESP, 1, São Carlos, 2007. Anais... São Carlos: EDUFSCar, 2007. p.17-8.

16 SHIRLING EB., GOTTLIEB D. Methods for characterization of Streptomyces species. Int. J. Syst. Bacteriol., 1966, 16, 313-40.

17 STROBEL G. Harnessing endophytes for industrial microbiology. Curr. Opin. Microbiol., 2006, 9, 240-4.

18 YOO JC., KIM JH., HA JW., PARK NS., SOHNG JK., LEE JW., PARK SC., KIM MS., SEONG CN. Production and biological activity of laidlomycin, anti-MRSA/VRE antibiotic from Streptomyces Sp. C5684. J. Microbiol., 2007, 45, 6-10. 